\title{
The Stage-Management of the leaders' personal lives in the 2015 General Election
}

La mise en scène de la vie privée des leaders durant la campagne législative de 2015

\section{Sabine Michelon}

\section{OpenEdition}

\section{Journals}

Electronic version

URL: http://journals.openedition.org/rfcb/515

DOI: $10.4000 / \mathrm{rfcb} .515$

ISSN: 2429-4373

Publisher

CRECIB - Centre de recherche et d'études en civilisation britannique

Electronic reference

Sabine Michelon, «The Stage-Management of the leaders' personal lives in the 2015 General Election », Revue Française de Civilisation Britannique [Online], XX-3 | 2015, Online since 01 December 2015, connection on 20 April 2019. URL : http://journals.openedition.org/rfcb/515 ; DOI : 10.4000/rfcb.515

This text was automatically generated on 20 April 2019.

\section{$\oplus \Theta \Theta \Theta$}

Revue française de civilisation britannique est mis à disposition selon les termes de la licence Creative Commons Attribution - Pas d'Utilisation Commerciale - Pas de Modification 4.0 International. 


\title{
The Stage-Management of the leaders' personal lives in the 2015 General Election
}

\author{
La mise en scène de la vie privée des leaders durant la campagne législative de
} 2015

\author{
Sabine Michelon
}

\section{Introduction: the publicization of the private persona}

1 Although the extent of their influence on actual electoral results remains debated, the promotion of the leaders' personalities is a prominent feature of electoral campaigning in Western democracies, in particular in the UK. It has been argued that the introduction of the leaders' debates in 2010 even reinforced the trend. ${ }^{1}$ As a matter of fact, Jeremy Paxman opened the debate section of The Battle for Number Ten by saying: "tonight we'll see what they are made of." It was an invitation for the public to make up their minds between "the only two who actually [stood] a chance of forming the next government" ${ }^{2}$ based on an assessment of their mediated personalities. This is in exact keeping with what Ana Inés Langer, upon whose seminal research this paper draws, wrote in the introduction of her book on the personalisation of politics: "issues and policies are identified with leaders, political successes and failure attributed to them and their political and personal qualities discussed, often in detail." Indeed, "leaders are increasingly expected to embody the party brand, personify the party's values and policies, (...) and function as the unifying narrative that links what often seems like a set of ideologically disjointed policy proposals." ${ }^{4}$

2 The issue of distinguishing between the personal and the political is an age-old feature of politics (the Romans called it the art of Janus, the two-faced god). However, the boundaries between the two seem to have become increasingly blurred, to the extent that David Cameron famously declared in the 2010 campaign that "the personal is political." This can be perceived as the culminating point of a move over the past two decades in the 
UK towards emphasising the personal lives and qualities of the leaders, their private spheres and inner selves. Langer argues that Blair's era modified expectations about both the actual and expected roles of the personal in public discourse, of which it has now become "a common and accepted feature." She further explains that both the media and the politicians coproduce the phenomenon, as both sides readily reveal all kinds of private details to the public. More importantly, there has been, as a result, a "broadening of what are considered leadership qualities", 7 that is to say, there have also been changes as to how relevant the personal is now deemed to be as far as evaluating leadership is concerned. The most striking element in this phenomenon is that the ability to present a "human" persona is now a "prerequisite of political and electoral success and a key marker of contemporary leadership potential". It has not led the "human being" to replace the leader, but has made the line between the two harder to draw than ever before. This shift is what Ana Inés Langer theorises in her work as the "politicization of the private persona."

3 This paper will focus on one specific aspect of personal image-building in the 2015 electoral campaign, which is the stage-management of the four national "major party"10 leaders' personal and family lives, based primarily on a corpus of televised portrait interviews: Tom Bradby and Julie Etchingham's ITV Tonight: Spotlight and James Landale's BBC Leader profiles. ${ }^{11}$ Even if they were conducted by senior political journalists in most cases, ${ }^{12}$ they can be described as "soft-focused" ${ }^{13}$ because of the central role devoted to the personal. The main corpus was essentially completed with relevant press articles commenting upon the programmes. Two main questions will therefore be addressed in this article: how were the leaders' personal spheres used for strategic publicity in the campaign? It will try and assess, as well as compare, and when necessary, contrast, the leaders' strategies in this respect. Secondly, to what extent did the media play a complicit or antagonistic role in the use of the personal to construct and/or consolidate the leaders' personae?

\section{Managing the leaders' personae}

4 The title of the BBC series of political portraits, "Leader profile", suggested that viewers/ voters would get to form an opinion of the politician under focus's ability to run the country through the depiction of his ${ }^{14}$ character. From this viewpoint, "leader profile" could be seen as synonymous with "political persona" (or simply "persona"), which can in turn be equated with a politician's public image or personality, which indeed includes his or her leadership qualities. The fact that the pieces all provided glimpses of the depicted leaders' personal lives is representative of Langer's key idea that the distinction between "leadership/political (or hard, performance-related)" and "personal/private (or soft) qualities" is "not straightforward" because these categories are "continuous rather than dichotomous." 15 It is relatively simple to identify which are situated at the opposite ends of the spectrum: " 'pure' leadership qualities" (defined as "personality traits that have a direct link to the leader's fitness and capability to govern"16) include for instance experience, competence, intelligence, strength, reliability, and honesty; on the other hand, being nice, interesting, cool, fun/good humoured, loving and family-oriented are clear personal qualities. Even so, presenting themselves as loving and family-oriented can influence the perception that a leader is reliable, and why not, honest, since they appear to be showing their inner or "true" self. The qualities that are of a "mixed personal/political nature"17 situated in the middle part of the continuum, such as social skills, are all the more complicated to qualify 
that they have been shifting along the spectrum as a result of the politicization of the private persona. Thus, and, to sum up, political and personal qualities are not, and cannot, be clearly separated in the media's or public's appraisal of politicians. In addition, the necessity to appear "human", that is to say "in touch" at least emotionally, operates within a broader technological, socio-economic and cultural context in which the concept of charisma in politics has been undergoing partial redefinition. Indeed, it no longer uniquely corresponds to some sort of "greatness", to "a certain quality of an individual personality by virtue of which he is considered extraordinary and treated as endowed with supernatural, superhuman, or at least specifically exceptional powers or qualities" as defined by Weber in $1968 .{ }^{18}$ It has now come to also entail the ability to generate a degree of identification. This is not to say that traditional leadership qualities are no longer deemed important, or more important, than softer qualities. However, they no longer suffice.

5 The original Latin meaning of the word persona is remarkably enlightening, since it referred to the theatrical masks worn by actors on stage. Thus, when applying the term to political leaders, the similarities between the professions cannot be ignored. ${ }^{19}$ In fact, James Landale, who conducted the BBC interviews, indicated in his comments about Nigel Farage's episode ${ }^{20}$ that filming took place under the chaperonage of the UKIP leader's media advisors. ${ }^{21}$ Two remarks must therefore be made: first, this is concrete proof that his appearance on the programme was a choreographed performance; secondly, it may reasonably be assumed that it was also the case on his Tonight Special episode, and crucially, that it was also true of all the other leaders' pieces under study in this article.

6 Although their individual circumstances vary, the four leaders have in common a rather, if not very, privileged background, which means that none of them could dispense with attempting to present themselves as convincingly "normal" so as to evidence their ability to relate to voters' daily lives and problems. Opening up about their daily family lives played an important role for the leaders of the three main parties, as shall be seen in the next part of this article, but another key element was to showcase how their experiences of personal hardship, which generally drew from their political lives and/or their family histories, accounted for their political commitment.

David Cameron's strategic uses of the personal in the construction of his public persona have been well documented throughout his political life in general ${ }^{22}$ and was even further analysed during the 2010 campaign. ${ }^{23}$ There is overall consensus that he had rather successfully "detoxified" the Tory brand through effective marketing of himself as "Chillax Dave", a family-oriented and environmentally conscious man full of youthful vitality, achieved by means of remarkable ease in the confessional mode, combined with clever use of photo-opportunities. The other side of the coin was that he was criticised for being too "packaged" and glossy. In fact, as far as the construction of his persona is concerned, Langer explains that he has been more than the "Heir to Blair", setting new milestones and asserting that the public is entitled to know about a leader's personal life. ${ }^{24}$ More importantly, because he was the incumbent Prime Minister, albeit in a Coalition government, his relative past success and continued media presence over the past five years had made him the yardstick against which others were measured in the political landscape of the 2015 election. Thus, given the "highly reactive" nature of leadership dynamics in the UK, his strategies could either be viewed as the ones to emulate, or to provide an "antidote" 25 to. Cameron's personal circumstances may well explain why it was so essential for him to develop ways of appearing "human" through unprecedented politicization of his family life. ${ }^{26}$ Indeed, it cannot be denied that the Prime Minister is 
archetypically posh: educated at Eton and Oxford-where he joined in the Bullingdon Club-, he rose to political prominence as part of the "Tory Notting Ill set". Such an extremely privileged background has always been used against him to suggest that he was out of touch with ordinary people, and that he was living proof that the Conservative party was the party of the rich. The 2015 campaign was no exception, and he was indeed on several occasions reminded of his origins, a situation he himself dubbed, heaving a sigh, "the old posh question" in response to James Landale's rather benign: "Has being posh held you back?" on his BBC Leader profile interview. ${ }^{27}$ Jeremy Paxman asked him bluntly and rhetorically: "This is one of the things that people really find problematic about you, I'm going to be personal if I may for a second, (...) what do you have in common with these very rich people?"28 Yet David Cameron's life has not been devoid of hardship on a personal level. He grew up with a handicapped father, and more tragically, he and his wife lost their severely disabled son Ivan in 2008, a topic he has been open about in a truthful and dignified way.

Ed Miliband, although from a middle-class background, went to Oxford like Cameron, and was even a visiting scholar at Harvard for a year. His insistence on the crucial role played by the local comprehensive school he and his brother attended ${ }^{29}$ in his life can be interpreted as a way of contrasting his more modest upbringing with Cameron's. Nevertheless, one of the many indictments against him has been his perceived aloofness. Paxman perfectly summarized the ins and outs of his image problem when he pointed out that people "see [him] as a North London geek." ${ }^{30}$ The word "geek" is defined in the MerriamWebster as "a person who is socially awkward and unpopular: a usually intelligent person who does not fit in with other people." First, it is a fact that he is commonly perceived as a "lofty intellectual" whose social awkwardness was infamously epitomised in the much-discussed disastrous bacon sandwich photo-op, ${ }^{31}$ ironically "intended to show what a normal guy he was ." Secondly, not only did a disgruntled electrician decry him for sounding "like a public schoolboy," ${ }^{33}$ but he was also reviled within his own ranks by Labour backbencher Simon Danczuk, who declared: "he has an image of being more of a toff than David Cameron. That's how the public see it. And what they mean by that is that he's seen as more aloof. They'd prefer to go for a pint with David Cameron than they would with Ed Miliband." ${ }^{34}$ One instance in which the political was truly personal in his case was the Labour leadership contest against his brother David in 2010. The topic was repeatedly brought about on his television appearances..$^{35}$ Each time, he addressed it in a similar wording to that of his official biography on the Labour Website: "It was a tough time for my family, but I thought Labour had to make some changes and that I was the best person to bring them about." ${ }^{36} \mathrm{He}$ also systematically added that it was "healing." ${ }^{37}$ In addition, Miliband was prompted by his advisors to introduce elements of his private life in his discourse, in particular the narrative of the influence of his Jewish refugee parents on his political views: " "If we win the election, I think millions of people will lead better lives, and that's what politics is all about, that's what my parents taught me." ${ }^{39}$

9 Even if he shares Miliband's middle-class origins and was educated at Cambridge, Nick Clegg's elitist credentials are usually presented as having to do with his cosmopolitan background and multicultural nuclear family (his mother is Dutch, his father AngloRussian, and his wife, Miriam González Durántez, is Spanish) which partly resulted in his ability to speak five languages. Albeit of a relatively different nature, they were still used against him by Evan Davis to argue that Europhilia had come to him so naturally that he could only find it difficult to relate to common people's reservations about the EU. ${ }^{40}$ The remark on the number of languages he can speak also smacked of the same anti- 
intellectualism levelled against the Labour Party leader. The focus on Nick Clegg as a person in the campaign was otherwise essentially about how he had been dealing with the extremely cruel personal attacks lashed out at him in the wake of the Liberal Democrats' broken promise concerning university tuition fees. ${ }^{41}$ His personal experience of hardship seems to have come with his political work. However, like Ed Miliband, he shared the story of how his mother was imprisoned for three years in a Japanese camp in Indonesia on his BBC interview, to show that he too knew of true hardship, even if, like Miliband, he had not experienced it first-hand either.

10 As to Nigel Farage, Evan Davis attempted to expose him as a hypocrite for claiming as a staple feature of his political rhetoric that he is nothing like "the liberal metropolitan elite" of the other parties by pointing out that he was in fact public school educated himself. The UKIP leader replied rather feebly that half of the boys in his school came from working class background (although he was not one of them). ${ }^{42}$ To quote Julie Etchingham, Nigel Farage's is a "one-pint-in-one-hand-one-cigarette-in-the-other-persona" ${ }^{43}$ (echoing his introduction on Loose Women a few days earlier as the "down-to-earth bloke who likes a pint and a fag"). ${ }^{44}$ It was designed, however much he may claim it to be otherwise ("that's what I do"), ${ }^{45}$ to be an "authentic" antidote to the "boredom" embodied by all the others leaders. ${ }^{46}$ Interestingly, if he was indeed interviewed by Etchingham in a pub (which was where she raised the topic of his persona with him), the BBC piece included no such setting; instead, he appeared aboard a ferry on his way to the European Parliament, in the Parliament itself, and in some Great War battlefields. Landale mused on the $\mathrm{BBC}$ website that "his [Farage's] media team are much much more reluctant to let him be filmed in pubs, pint and fag in hand", and offered the following analysis: "It is almost as if they want to present a more professional, less jokey narrative." ${ }^{47}$ The UKIP party leader is not, however, entirely out of tune with his competitors concerning the incorporation of the experience of personal hardship in his political narrative, although he was reticent to talk about the difficulties in his childhood. ${ }^{48}$ However, his rather extraordinary personal history may well give him the upper hand in this area, given that he can truly label himself as a "survivor", having beaten cancer and come out alive of both a plane and a car accident. He builds on this image to project himself as an unstoppable force for change.

\section{The stage-management of family life-public fatherhood}

11 Ana Inés Langer points out that crucial though the narrative of the personal journey may be in the construction of a leader's persona, it cannot be substituted for the role played by family life. In particular, public fatherhood is a remarkably useful strategic instrument in terms of image-building since it "can help infuse a leader's persona with key leadership attributes such as kindness and reliability while at the same time reinforcing authoritativeness." 49 It can also be argued that in the context of Cameron's continuation and expansion of Blair's practices in this respect, expectations have changed further, and that it may no longer be dispensed with as a tool for both the media's and the public's assessment of these qualities. In fact, although strategies varied among them, the leaders of the three main parties were committed to presenting themselves as good, ordinary fathers in spite of their extraordinary political circumstances. ${ }^{50}$ Indeed, Ed Miliband's: "my most important job is being a dad" ${ }^{11}$ was echoed by Nick Clegg's: "I am a dad, ${ }^{52}$ and a husband before I am a politician, and I will be a dad and a husband long, long after I've left politics." ${ }^{53}$ As to the Prime 
Minister, Tom Bradby commented on the topic of his family life: "this is the first clue to David Cameron, no one who knows him can doubt that this is where his heart lies." ${ }^{54}$ Nevertheless, Nigel Farage clearly and voluntarily stood out by confessing on Loose Women that he is on the whole a poor family man, even if he acknowledged that becoming a father was the "most phenomenal experiences in [his] life," 55 and gave other hints as to his love for his children.

The key strategic question that arises for political leaders when it comes to opening up about their lives as parents is the extent to which they are willing to expose their children. Both David Cameron and Ed Miliband had theirs feature prominently (the same was true of their wives) in their BBC and ITV portraits. There was however one fundamental difference in the way the Prime Minister's and the Labour Leader's children appeared on TV: the two little Milibands (Daniel, 5 and Samuel, 4) were fully shot, whereas the faces of the three young Camerons (Elwen, 9 Nancy, 11, and Florence, 4) were never shown. Thus, a hasty conclusion might have been that the Milibands were rather reckless in prioritising alleged political gain over their offspring's right to privacy, while the Camerons had found the more responsible way of playing the family life disclosure game by still providing their children with protection from the public eye. However ITV's Tom Bradby revealed the truth of the matter: "for security reasons we have agreed not to identify the children here." ${ }^{56}$ By contrast, both Nick Clegg and Nigel Farage have always refused to throw their children in the limelight. The UKIP leader, who is a father of four, was content with telling ITV's Julie Etchingham that "they're all doing very well in life, and I'm pleased about that" after saying, with no further comment: "you're not going to see their pictures, cause I'm keeping them out of the public view, ${ }^{57}$ implying that he viewed the statement as self-explanatory. Nick Clegg made a similar statement on his LBC phone-in show: "You might catch glimpses of my kitchen, ${ }^{58}$ you certainly - I hope - will catch sight of Miriam. You will never catch sight of my children." ${ }^{59}$ His tone was even firmer than Farage's (" you will never"), and the line was all the better drawn that he proved perfectly aware of contemporary expectations in terms of publicization of the private persona as he conceded that he might yield to the media pressure to show his kitchen and reminded the public that his wife's was not to be used as a prop, and that any appearance she would make would be very much her own decision. As a matter of fact, he said absolutely nothing himself about his children on either of his portraits: on the $\mathrm{BBC}$, it was his mother who rapidly mentioned them while really describing her son and daughter-in-law as parents ("he and Miriam have a lovely relationship with their children, they are very dedicated parents"), ${ }^{60}$ and on his Tonight Special episode, they were very subtly hinted at through quick shots on handcrafted gifts from them that he keeps in his Downing Street office like any other parent, and were mentioned once and then alluded to by his wife. Both Clegg and Farage were critical of the Conservative and Labour leaders' choices: commenting on the Battle for Number Ten, Farage turned on David Cameron for "bringing in his children every time he could." ${ }^{1}$ But it was Nick Clegg who carried out the harshest attack, through perfect antiphrasis, when he quipped on the above-mentioned LBC show: "I am not making oblique criticism of David Cameron or Ed Miliband. I have always felt very, very strongly that my children are entitled to an innocent childhood just as much as any other kids." ${ }^{62} \mathrm{He}$ further highlighted his determination by explaining: "I don't want them when they go to school to suddenly have someone sitting next to them saying 'I saw you on telly'. It makes them feel different. $\eta_{63}$ 

circumstances of their lives as politicians was actually shared by almost all leaders beyond the issue of protecting them from public scrutiny, but "normalcy" covered different meanings. For instance, the notion of "home" as a safe haven played an important role for both the Cameron and Clegg families, but was not mentioned by the Milibands. David Cameron summed up the matter when he told Susanna Reid: "You can't insulate your children from what you do, you just try to create, you know, a warm home" ${ }^{64}$ and explained later on to James Landale that the weekends in their Oxfordshire constituency home were essential to enable his children to keep their bearings: "you know London was their home and they are at school in London, but because we live in number 10, which one of my children calls 'the pretend home', (...) it's very important that they feel rooted and grounded here." ${ }^{65}$ His wife Samantha even confided on ITV that she initially felt extremely anxious about the potential impact of life at Number Ten, but that they had found ways of preventing a complete overhaul: "It's been much easier than I expected it to be, I go to the same office, the children go to the same school. There's a lot of our life that hasn't changed." ${ }^{66}$ The Cleggs' ${ }^{\prime 67}$ choice not too uproot their children when he joined in the Coalition government was first brought about on the above-mentioned LBC show, when he explained that he and his wife had declined "to move into a great fancy flat behind the battlements of Downing Street or Whitehall"68 and that his family "still [lived] live in the home that [they] did before [he] became deputy prime minister." The topic was raised again in the couple's joint interview for ITV, and it was revealed that they had been quite under a lot of pressure to move, but had decided against in order to protect their children.

Yet the main challenge political leaders appeared to be faced with was to be able to provide their children with a "normal" life in the sense that they would not be deprived of their love, care and attention because of their extremely busy schedule. Thus, the leaders appeared juggling work and family life, or, in the case of Nigel Farage, failing to do so. Indeed, when asked whether he found time to spend with his wife and children by one of the Loose Women, the UKIP leader gave the following answer:

At the moment I don't and I was very clear about that (...), I said you know, you cannot conduct any sense of family life and do politics. Now I notice how the three big party leaders are very good at coming on programmes like this and say what wonderful family men they are and how they do the school run and when the babies were little they changed the nappies and did the night feeds. Maybe that's true but all I can say is that my life in politics... it is pretty much impossible to do that. ${ }^{69}$

Farage succeeded in counterpoising his potentially damaging confession ${ }^{70}$ that his wife was more than bearing the brunt of childcare by casting doubt on his competitors' presentation of themselves as hands-on fathers. He was also slightly dishonest in putting Nick Clegg on a par with David Cameron and Ed Miliband, given that the Lib-Dem leader is almost as spare about details of his family life as he himself is. ${ }^{71}$ However, Farage qualified his discourse later on by declaring that he was "not particularly proud of how he [had] been running his family", and by provocatively saying that he would consider quitting politics to become a househusband if he lost the election in order to make up for his mistakes..$^{72}$ The one serious concern he expressed as to the toll taken by his political career on the normalcy of his children's lives was of a different order compared with the other leaders: indeed, he explained on both the BBC and ITV that they sometimes went through hard times because they were easily identified with him on account of their "unusual surname".

Revue Française de Civilisation Britannique, XX-3 | 2015 
16 Ed Miliband first expressed his frustration at not getting enough time with his children on the BBC piece (as a matter of fact, his wife Justine also mentioned it), and even made the touching confession that it was one of the things he worried about when he thought about his future life if he won the election: "obviously I think about what would happen if was Prime Minister, and making sure there's enough time." He was nevertheless shown spending quality time with them and his wife Justine in the park on both his BBC and ITV portraits. Asked what type of father he was on Good Morning Britain, Miliband answered: "I'm the kind who likes to tell stories," ${ }^{73}$ as had been exemplified at the beginning, pursuing the family tradition invented by his late father. The Miliband boys were shown as normal happy little boys enjoying a ride on their scooters in the park. On the BBC piece, they commented on how "daddy" was always on the phone, or at work.

The Prime Minister, however, was presented as moving seamlessly from one role to the other, notably in the ITV piece, in which the marble table of the Downing Street flat was offered as the symbol of his effortless ease in "[switching] from the matters of state to the business of the school run" as he simply explained: "you can see this is my work table but in a minute it's gonna be a breakfast table." In his case, even the personal table is political. Time did not seem to be an issue: "I like living above the job because I get to see my children." 74 The Prime Minister's children's coverage consisted in mundane scenes of domestic happiness: they were shown discussing things with their parents over breakfast on ITV (which had already been done in the 2010 campaign) and over lunch on the BBC, as well as in a $\mathrm{PEB}^{75}$ using footage obviously shot on the same day. On the ITV piece, the conversation was about school dinners and costumed book day at school. The latter topic provided Cameron with the occasion to mention Elsa, thereby proving that, he was perfectly in touch with the overwhelming success and ubiquitous merchandising of Disney's Frozen. The $\mathrm{BBC}$ portrait only featured snippets of talk with the children at the end of the piece, but these included the happy ending of the Camerons' eldest daughter Nancy's "hunger strike", which the Prime Minister had previously explained had led to an important conversation between them. He thus further evidenced his parenting skills by showing that discussion is the way problems are solved in his home. He had already shown himself as a good father like any other by going to support his son at his football game in the opening of the piece. In addition, he was seen doing his share of the school run on ITV, tying his daughter's hair with a band before giving her a kiss. The close-up on his hands showed that he was handling it rather well, in an attempt to prove that it was not a mere stunt, but something he was comfortable with out of practice. It is worth noting that throughout the campaign, he constructed a consistent persona of his eldest daughter Nancy as an independent (she was apparently sewing her book day costume herself on the ITV piece) smart young girl with a sense of humour (it was revealed in the Sunday Times that she compares him to Phil Dunphy from the American sitcom Modern Family, and that she found the "kitchengate" hilarious), ${ }^{76}$ but also aware of radical means of political action (when she allegedly went on a hunger strike for the reinstatement of Jeremy Clarkson on the motoring programme Top Gear). The latter element says something about how he and his wife Samantha are raising her in a spirit of gender equality, which was also alluded to by the Prime Minister's agreement to be seen doing her hair on ITV, showing that the distribution of tasks in the Cameron household is not defined by traditional gender roles. ${ }^{77}$ 


\section{The "secret weapon" is the new "ordinary political spouse"} party leaders' wives was pointed out by Higgins and Smith as one of the most notable of the many innovations in the 2010 campaign. They found that it resulted from a combination of three factors: "party communication strategy, established media discourses, and the agency and visibility of the wives themselves." ${ }^{78}$ Indeed, although in different ways, neither of the women involved in 2010 fit in the mould of the "ordinary political spouse", who provides silent yet smiling support to their powerful other half through strategic appearances by their side at political events, and possibly act as signposts for their moral worth as husbands. Since both Samantha Cameron and Miriam González Durántez were involved again, it could reasonably be assumed that the trend would be continued in the 2015 election, not to mention that their status as wives to the two most important figures in the British government over the past five years meant that they had both had continued media presence and had developed a rather high media profile in their own right. Justine Miliband had also received some media attention over the same time period as the spouse of the leader of the opposition, it was by no means comparable to the other two, even if she had taken her real first steps into the limelight a few months ahead of the campaign at the Labour Party conference.

Although Higgins and Smith ${ }^{79}$ explained that wives such as Margot Asquith or Mary Wilson had previously contributed to the political realm in their own terms, once again the most tremendous changes were introduced in the Blair era, when his wife Cherie became a public figure in her own right, who "flitted across a range of press identities, from the domestic role of 'wife' to the professional position of 'barrister', bridged by the combined role of 'working mother." "'0 The multiplicity of roles attributed to Cherie Blair still holds true as far as the coverage of the three wives under focus in this part is concerned: indeed, Samantha Cameron, Miriam González Durántez and Justine Miliband are all cast (or cast themselves) in turn as instruments offering a way into the domestic realm, adding elements of ordinariness to their husbands' personae in their role as their "wives" and as the mothers of their children, quite in the same manner as the children themselves do, while conducting high-flying careers; as a matter of fact, both Miriam González Durántez and Justine Thornton ${ }^{81}$ work full-time as barristers like Blair's wife, while Samantha Cameron is a creative consultant for the leather company Smythson, though she has reduced her working hours to two days a week since her husband was elected. Cherie Blair found herself the object of media backlash because she often expressed her independence, thereby refusing to "occupy a silent position of commitment to her (...) husband, $" 82$ and was often vilified in the right-wing press which enjoyed portraying her as scheming "Lady MacBeth Character". However this was not the case of three leaders' wives under focus in this article. Their coverage was seldom aggressive, although Nick Clegg's wife has occasionally been portrayed as a feminist bully, in the same right-wing press $^{83}$.

One of the essential roles of a political leaders' wife is to provide them with support, both in the public and in the private realm. Naturally, it consists first and foremost in backing them politically. Indeed, all voiced their support for their spouses' political ambitions. While Samantha Cameron simply declared about her husband David that "he's the best man 
for the job," ${ }^{84}$ Miriam González Durántez chose to argue for the Liberal-Democrat Party as a whole rather than to lay the focus on the sole figure of Nick Clegg, moving away from personalisation: "I have seen Nick and these guys for five years putting country above party consistently, every single day - very often at a great personal cost. They deserve to be back." ${ }^{85}$ Justine Miliband was even more elaborate as she-now famously-said on the BBC early in March that she expected the personal attacks on her husband to get worse, "vicious", and that she was "totally up" for the "fight": "because I think this goes way beyond Ed as an individual, I think it's about whether decencies and principle count for something in political life, wherever you are on the political spectrum" and added that she had decided to give a speech in the last Labour Party Conference because she wanted to "reassure people that [she] was in fact more than a dress." ${ }^{86}$

21 Samantha Cameron was the wife who received the widest media coverage. ${ }^{87}$ She has always been willingly in the public eye in the role of the spouse, both by her husband's side and through regular charity work. Consistently, during the campaign, she joined in on the campaign trail both with the Prime Minister and on her own within the framework of charity events. On both the BBC and the ITV pieces she spoke almost exclusively of family life and how she and "the kids" keep the Prime Minister "grounded". ${ }^{8}$ In addition, she gave a Sunday Times interview in which she opened up about the loss of her son Ivan. ${ }^{89}$ Miriam González Durántez has often been said to be reluctant to be cast in a politician's wife role. Indeed, during the campaign, she only appeared very briefly in a joint interview at the end of the ITV piece, and was physically, albeit not entirely (she was mentioned and a photograph of her was shown), absent from the BBC Leader profile. Her stand-alone interviews during the general election campaign were always given primarily within the framework of her "Inspiring Women" campaign, which is about providing girls age 13-15 with real-life role models by having professional women coming to talk to them. She did join in on the campaign trail late in April, to support women Liberal-Democrat candidates, in keeping with her feminist work. Like Samantha Cameron, she appeared to play a key role in making sure her husband did not lose touch with reality. Commenting on the decision not to move to Whitehall when her husband became Deputy Prime Minister, she said:

If you look at it with perspective it has been the best decision for all of us and if I may, also for Nick as well because you can see how politicians sometimes can get in a bubble and be completely distant from normal society and I think if you're in your house in your neighbourhood, it's much easier really.90

Her husband's BBC piece was Justine Miliband's first major interview, although she had started getting more involved since she gave a speech at the previous Labour Party conference. In James Lansdale's opinion, the Labour Party intended to spark a debate about character, and portray Ed Miliband as a decent man trying to bring change to Britain. He purports that within this framework, they must have hoped Justine Miliband would prove an asset, like Sarah Brown seemed to have been for her husband Gordon, " possibly knocking the edges of her husband's image, and perhaps helping him connect with voters." ${ }^{91}$ Her role in helping him keep his feet on the ground was not mentioned in the portraits, however Miliband did mention his official Labour autobiography that: "My wife Justine (...) has done more than anyone to keep me rooted in real life over the last few years." ${ }_{92}$ 


\section{The "kitchen election"}

24 by essence, a key role: they are an integral part of the performance. As a matter of fact, what can be seen may even become more important than what is being said when viewers' focus on the latter falters, whether by choice of out of loss of attention. Thus, all elements of visual presentation matter in the ultimate reception of the message conveyed: the speakers' body language and physical appearance (clothes, haircut) on the one hand, but also the visual background provided by the setting. It has already been noted that the chosen locations of the filmed interviews of all four leaders were more or less instrumental in bestowing consistency to their intended messages, whether explicit or implicit (Cameron's breakfast table, Miliband's comprehensive school, Clegg's office, Farage's BBC settings). Given the highly confidential tone of the main televised corpus of this article, it is hardly surprising that the TV crews were let into their private homes. ${ }^{93}$ However, the cameras were let further in than the expected reception spaces that are the living or dining rooms; indeed, David Cameron, Ed Miliband and Nick Clegg were all seen in their kitchens, and what was truly remarkable about the 2015 election was the media frenzy generated by these specific rooms, in particular in the wake of the revelation that the kitchen the Milibands were filmed in by the BBC was one of the two they have in their house. It was treated much like a sleaze scandal, and led to media talk about a "kitchengate " and to the leader of the Labour party being dubbed "Ed 'Two Kitchens", in reference to the former Labour Deputy Leader "John 'Two Jags"' Prescott. Only Nigel Farage kept the cameras away from his home in general and from the room in particular, in usual keeping with his private persona strategy.

Though the UKIP leader did not show his kitchen, he did however mention his cooking credentials in a Mirror interview, but presented them in a "manly" way: "I'm not a new man, but I can cook, I particularly like cooking things I've caught." ${ }^{44}$ Both Ed Miliband and David Cameron were filmed cooking simple meals, probably to show off their man-of-thepeople credentials. When present, their wives stood by their side watching, in a modern redistribution of traditional gender roles. The Labour Party leader sought to evidence that his first-floor kitchen was indeed "for tea and snacks" 95 as he prepared eggs-on-toast for his children and his interviewer Tom Bradby, while the Prime Minister was shown putting together a sardine-and-mayonnaise sandwich for himself and the filming crew behind the cameras of his \#SunNation video. The inclusion of some of the media professionals involved at their tables was useful in alleviating the pure pseudo-event dimension of the act. Cameron repeated the performance on his BBC Leader profile, this time chopping tomatoes for a salad for his Sunday family lunch. As far as the Cleggs were concerned, unusually, the talk about cooking was exclusive to the Lib-Dem Leader's wife Miriam. Even more surprisingly, she mentioned on at least two occasions ${ }^{96}$ her passion and talent for spending time in the kitchen, and even revealed that she had been a secret food blogger for the past couple of years. ${ }^{97}$ For all that, such revelations strengthened her image of epitome of the over-accomplished $21^{\text {st }}$ century woman who could not be more successful at combining an outstanding career, charity work, motherhood and a perfectly egalitarian and blissful marriage.

The Milibands were the first to be filmed in their kitchen, on the Labour Party Leader's BBC profile. Scrutiny of the room immediately gave rise to mixed media coverage, 
depending on the political side of the newspapers involved. The harshest piece, penned by Sarah Vine, was published in the Daily Mail. Its title was eloquent enough: "Why their kitchen tells you all you need to know about the mirthless Milibands... and why there's nothing to suggest that Ed and Justine are not, in fact, aliens." ${ }^{98}$ The Milibands decided to laugh it off, not quite unlike the bacon sandwich incident, and even invited the cameras in a second time for the ITV Tonight Special episode. The "Kitchengate" was interpreted in the right-wing press as "a brilliant metaphor for Ed Miliband's failure to connect with Middle England's aspirational voters." ${ }^{99}$ The Prime Minister and the leader of the opposition even clashed over the issue in PMQs. There came to be so much talk of kitchens that it became expected that the Cleggs would in turn show theirs, ${ }^{100}$ which they did on ITV, not after displaying humorous awareness concerning the matter: Miriam González Durántez quipped on LBC: "I have only one kitchen," 101 while Nick Clegg had declared: "you may catch glimpses of my kitchen." According to a Times article, they passed the test with flying colours. ${ }^{102}$

Two press articles went so far as to provide forensic analysis of the Camerons' two kitchens, the one in their Cotswolds family home shown on the BBC and the one in their Downing Street flat ${ }^{103}$. The angle was typical of the Daily Mail's celebrity-based approach to politics, indeed, the layout was similar to their detailed dissections of celebrity outfits; however the publication of an even more elaborate piece in the quality paper the Daily Telegraph, complete with an interactive interface (while the Daily Mail simply included paragraph-long captions) was more intriguing, not to mention that it predated it. Not only was every single visible piece of produce in the pantry tagged, but it was also accompanied with comments on the choices in oil and vinegar. There appeared to be oblique criticism of the Cameron's failure at concealing their poshness. The comparison with "most families" was in fact limited to the "staples" "milk", "ketchup" and "Marmite", the latter being an indispensable feature of Britishness. In truth, it was almost immediately debunked with the mention of the "strangely neat pantry", which could either hint at their having professional help to keep their home immaculate, and/or to the presentational efforts made for the sake of stage-management. Similarly, the "American-style fridge freezer ", unambiguously alluded to their financial means. The rather gentle exposure culminated with the remark that there are in fact "some clear markers as to [the Cameron's] roots in the Notting Hill quinoarati set", with the mention of the South-American cereal which has been all the rage in the plates of the trendy health and environment conscious upper-middle classes over the past couple of years.

In the Daily Telegraph, Tim Stanley ${ }^{104}$ both argued and lamented that Ed Miliband's kitchens only mattered because of lesser differences between the parties. To him, the Labour Leader's kitchen problem did not lie in the fact that it revealed that he had money, since Labour leaders had already had to make up for being rich and well-educated through public display of connection with the middle classes in the past. ${ }^{105}$ To Stanley, " the difference between Wilson and Miliband is partly that the modern voter is trained to recognise political choreography and spot the strings - hence a photo-op in a kitchen that clearly isn't an everyday kitchen won't work." 106 His ultimate conclusion was that "Miliband fails to convince as a socialist not simply because he's personally rich but because Labour won't and can't offer a serious alternative to Tory policy." Thus, though Stanley provocatively went as far as to say in the opening of his article that in the 2015 election kitchens came first and ideas second, echoing the common contemporary concern that "style" has won over "substance", his core argument is that it is in fact not the case. More importantly, he 
acknowledges the public's awareness of the marketing techniques at work in any politician's attempt to present themselves under a specific light, and himself contributes to pointing them out, revealing the vulnerability of the parties' intended propaganda machines. Kitchen articles in particular showed that the media were not simply passive, but could play an antagonistic role (while the main corpus interviews had been little confrontational).

\section{Conclusion}

Langer points out that one major concern is that the politicization of the private persona has diminished political debate, and that "style" may have won over "substance", that is to say, over ideas and policies. By providing pseudo-insights into the personal lives of politicians, the phenomenon is blamed for trivializing and depoliticising the public sphere, diminishing the quality of political information and distracting from the substance of politics. It is a fact that human stories and personal narratives do make coverage more appealing in what has been described as a context of "tabloidization of the media", which is itself the product of intense commercial pressure. ${ }^{107}$ However, such softer coverage can also be a strategy to divert attention from more pressing issues, as was analysed by a number of journalists in the context of the "kitchengate." 108

This study gave further evidence that the stage-management of the private and family lives of the leaders was a highly choreographed matter. Indeed, if the same arguments on topics of policy were made almost verbatim from one media outlet to another, the same was true of the presentation of the leaders' personal lives and selves: words and stunts were often repeated. Yet even the Prime Minister's highly controlled media operation was not immune to glitches: at some point in April, he made an embarrassing gaffe that exposed his love of football as fake, when he mistakenly wished West Ham good luck, instead of his "official" favourite Aston Villa. Personal experiences and examples were systematically politicized, used for political means, "woven into ideological commitments, used to infer and underwrite political values as well as used to try and legitimize political positions. ${ }^{109}$ In addition, a most prominent feature of the use of the personal was how it was used to make adjustments to the leaders' perceived personality in order to meet voters' alleged expectations.

31 On the topic of comparing strategies, what was most striking was that there were clearly converging trends for the two main party leaders on the one hand, and for the two secondary party leaders on the other hand, which was simply consistent with the general marketing of their parties as offering an alternative. The reason why Ed Miliband's strategies were so similar to Cameron's is however less straightforward. It could be argued that the Labour Party leader's readiness to expose his family life stemmed from a perceived need to play by the rules of the winners of the previous elections, Blair and Cameron, and from the fear that if he failed to do so, he might be further compared with his predecessor Gordon Brown in terms of lack of communication skills. Indeed, Brown's reluctance to talk about his private life was interpreted as a sign of aloofness and invited suspicions of concealment. In this context, Farage's success at keeping his family life private and avoiding such criticism is all the more astonishing. The truth of the matter is that he could afford being reserved on the topics of his childhood and private life because the means of asserting the authenticity of his persona lie elsewhere. Given the increased awareness of the public as to the routine of political communication, his claims of 
authenticity seemed all the more self-fulfilling that he did not indulge in the same sort of photo-ops as the candidates who actually stood a chance of becoming Prime Minister.

\section{BIBLIOGRAPHY}

<http://www.labour.org.uk/people/detail/ed-miliband>accessed 31 May 2015.

A Day in the Life of David Cameron, \#SunNATION, 18 March 2015, <http://www.sunnation.co.uk/ david-cameron-day-in-a-life-video-sunnation-exclusive/>, accessed 31 May 2015.

“Cameron Defends Filming of Family”, BBC News, 14 March 2008, <http://news.bbc.co.uk/2/hi/ uk_news/politics/7295735.stm>, accessed 31 May 2015.

“Ed Miliband-a Portrait”, Labour Party PEB, 28 April 2015, <http://labourlist.org/2015/04/edmiliband-a-portrait/>, accessed 29 April 2015.

“Londoner's Diary: Miriam González Durántez: MPs can Learn it All at the School Gates”, Evening Standard, 27 February 2015.

BALE, Tim. Five Year Mission-The Labour Party Under Ed Miliband, Oxford: Oxford University Press, 2015,320 p.

BERH, Raphael. “The Making of Ed Miliband”, Guardian, 15 April 2015.

CAMERON, David. “My Credo for my Country”, Daily Telegraph, 2 April 2010.

CAMERON, D. \& MILIBAND, E. Interview with PAXMAN. Cameron \& Miliband Live: The Battle for Number 10, Channel 4/Sky News, 26 March 2015.

CAMERON, David. Interview with REID, Susanna, Good Morning Britain, ITV, 17 March 2015.

CAMERON, David. Interview with LANDALE, James. Leader profile, BBC, 23 March 2015.

CAMERON, David. Interview with BRADBY, Tom. Tonight: Spotlight, Series 22, Episode 1, ITV, 7 April 2015.

CLEGG, Nick. Call Clegg: Nick's Weekly LBC Phone-In, LBC, 12 March 2015.

CLEGG, Nick. Interview with LANDALE, James. Leader profile, BBC, 20 March 2015.

CLEGG, Nick. Interview with BRADBY, Tom. Tonight: Spotlight, Series 22, Episode 2, ITV, 9 April 2015.

CLEGG, Nick. Interview with DAVIS, Evan. BBC Leader Interviews, BBC, 13 April 2015.

COWBURN, Ashley. "Exclusive: Labour MP Says the Public Thinks Ed Miliband is Aloof and more of a Toff than Cameron", New Statesman, 23 March 2015.

DEACON, David. “A Tale of Two Kitchens, Two Jobs, Two Receipts”, Loughborough University blog, 8 April 2015, <http://blog.lboro.ac.uk/general-election/a-tale-of-two-kitchens-two-jobs-and-tworeceipts/>, accessed 31 May 2015.

FARAGE, Nigel. Interview on Loose Women, ITV, 5 March 2015.

FARAGE, Nigel. Interview with LANDALE, James. Leader profile, BBC, 6 March 2015. 
FARAGE, Nigel. Interview with DAVIS, Evan. BBC Leader Interviews, BBC, 22 April 2015.

FARAGE, Nigel. Interview with ETCHINGHAM, Julie. Tonight: Spotlight, Series 22, Episode 4, ITV, 23 April 2015.

FOLEY, Michael. John Major, Tony Blair and a Conflict of Leadership: Collision Course, Manchester: Manchester University Press, 2002, 213 p.

GABER, Ivor. “The 'Hollowed-Out Election,' or Where did All the Policy Go?", Journal of Political Marketing, vol. 12, n²-3, 2013, pp.211-225.

GILMAN, Ollie. "Forget the General Election, Vote Here on the REALLY Important Political Issue of the Day: Who's Got the Best Kitchen?", Daily Mail, 24 March 2015.

GLAZE, Ben. “Nick Clegg's Wife Delivers Slap Down to David Cameron for Living in a 'Bubble'”, Daily Mirror, 9 April 2015.

GONZÁLES DURÁNTEZ, Miriam. Webchat, Mumsnet.com, 21 April $2015<\mathrm{http}$ :// www.mumsnet.com/Talk/mumsnet_live_events/2359918-Webchat-with-Miriam-Gonz-lez-Durntez-Tues-21st-April-11-30-am?pg=5>, accessed 31 May 2015).

GONZÁLES DURÁNTEZ, Miriam. Interview with Shelagh Fogarty, Live on LBC, LBC, 25 March 2015. GOURÉVITCH, Jean-Paul. L'image en politique, Paris: Hachette, 1998,

$247 \mathrm{p}$.

GRIEG, Geordie. "Samantha Cameron: 'Dave Runs the Country; I Do the School Run'“, Mail on Sunday, 4 April 2015.

HALLIWELL, Rachel. "Politicians: Get out of the Kitchen (but not Before

Showing us your Smeg)", Daily Telegraph, 25 March 2015.

HARMER, Emily. “Men Writing About Men: Media And The UK General Election 2015”, Loughborough University blog, 22 May 2015, <http://blog.lboro.ac.uk/general-election/menwriting-about-men-media-and-the-uk-general-election-2015/> accessed 31 May 2015.

HIGGINS Michael \& SMITH Angela. “'My husband, My hero': Selling

the Political Spouses in the 2010 election", Journal of Political Marketing,

vol. 12, n² 2-3, 2013, pp. 197-210.

HODGES, Dan. “I couldn't Care less about Ed Miliband's Kitchen”, Daily Telegraph, 13 March 2015.

KNOWLES, Tom. "No Kitchen Sink Dramas as Cleggs Let TV crew into Lome”, Times, 9 April 2015.

LANDALE, James. “Leader Profile: 24 hours with Nigel Farage”, bbc.co.uk, 6 March 2015, <http:// www.bbc.co.uk/news/uk-politics-31771963>, accessed 29 April 2015.

LANDALE, James. “A Chat with Justine Miliband”, bbc.co.uk, 10 March 2015, <http:// www.bbc.com/news/uk-politics-31825792>, accessed 29 April 2015.

LANGER, Ana Inés. “The Politicization of Private Persona: Exceptional Leaders or the New Rule? The Case of the UK and the Blair effect", International Journal of Press/Politics, vol. 15, $n^{\circ} 1$, January 2010 pp. 60-76.

LANGER, Ana Inés. The Personalisation of Politics in the UK: Mediated Leadership from Attlee to Cameron, Manchester: Manchester University Press, 2011, 256 p.

MERRICK, Jane. “Ed Miliband's Trial by Media: Damned if he Does and Damned if he Doesn't", Independent, 15 March 2015. 
MILIBAND, Ed. Interview with LANDALE, James. Leader profile, BBC, 10 March 2015.

MILIBAND, Ed. Interview with SHEPARD, Ben. Good Morning Britain, ITV, 25 March 2015.

MILIBAND, Ed. Interview with BRADBY, Tom. Tonight: Spotlight, Series 22, Episode 3, ITV, 16 April 2015.

MILIBAND, Justine. Interview with LANDALE, James. Leader profile, BBC, 10 March 2015.

MILIBAND, Justine. Interview with BOOT, Megan. ITV Cymru Wales, 23 April 2015.

MILIBAND, Justine. Interview with RIDGE, Sophy. Sky News, 3 May 2015.

Ofcom, Ofcom List of major parties, 16 March 2015, <http://stakeholders.ofcom.org.uk/binaries/ broadcast/guidance/major-parties.pdf>, accessed 17 March 2015.

OWEN, Pamela. “Nigel Farage: 'If I Lose I May Quit Politics to Become a House Husband”, Daily Mirror, 11 April 2015.

RAINEY, Sarah. "Inside the Camerons' OTHER Kitchen - with its £22 Ikea ceiling lights, £239 John Lewis Food Processor, a £87 Panasonic Bread Maker - and a Calm Down Dear Chopping Board", Daily Mail, 24 March 2015.

RILEY-SMITH, Ben. “Ed 'Two Kitchens' Miliband under Fire in Bizarre Row”, Daily Telegraph, 12 March 2015.

ROSE, Hillary. "Never Mind the Cabinet: this Election is Being Fought in the Kitchen", Times, 19 March 2015.

SEAWRIGHT, David. “'Cameron 2010': An Exemplification of Personality-Based Campaigning”, Journal of Political Marketing, vol. 12, n² 2-3, 2013, pp.166-181.

SHIPMAN, Tim. “Cameron's Just a ‘Sad Dad' to his Daughter”, Sunday Times, 12 April 2015.

SMITH, Gareth. "Conceptualizing and Testing Brand Personality in British Politics", Journal of Political Marketing, vol. 8, n³, 2009, PP. 209-232.

STANLEY, Tim. "British politics has a surfeit of kitchens and a deficit of ideas", Daily Telegraph, 16 March 2015.

SWINFORD, Stephen. "Video: Ed Miliband Sounds like a Public Schoolboy", Daily Telegraph, 20 February 2015.

VINE, Sarah. "Why their Kitchen Tells you All you Need to Know about the Mirthless Milibands... and Why there's Nothing to Suggest that Ed and Justine are not, in Fact, Aliens", Daily Mail, 12 March 2015.

WALLIS SIMONS, Jake. “Why are so Many Men Attracted to Ukip?”, Daily Telegraph, 26 February 2015.

H. WALLOP \& M. OLIVER. “The 45 Secrets of David Cameron's Middle Class Kitchen” Daily Telegraph, 20 March 2015.

WATT, Nicholas. “Kitchen Sink Drama for Miliband as Homely Photo Backfires”, Guardian, 12 March 2015.

WOLLATSON, Sam. “Spotlight - Ed Miliband: Tonight review: ‘Personality'n'politics, Easy Over”', Guardian, 17 April 2015. 


\section{NOTES}

1. See Ivor GABER, “The 'Hollowed-Out Election,' or Where did All the Policy Go?", Journal of Political Marketing, vol. 12, $\mathrm{n}^{\circ}$ 2-3, 2013, p.212.

2. David CAMERON \& Ed MILIBAND, Interview with Jeremy PAXMAN, Cameron \& Miliband Live: The Battle for Number 10, Channel 4/Sky News, 26 March 2015.

3. Ana Inés LANGER, The Personalisation of Politics in the UK: Mediated Leadership from Attlee to Cameron, Manchester: Manchester University Press, 2011, p.1.

4. Ana Inés LANGER, "The Politicization of Private Persona: Exceptional Leaders or the New Rule? The Case of the UK and the Blair Effect”, International Journal of Press/Politics, vol. 15, n¹, January 2010, pp.61-62.

5. David CAMERON, “My credo for my country”, Daily Telegraph, 2 April 2010.

6. Ana Inés LANGER, 2010, p.61.

7. Ana Inés LANGER, 2011, pp.2-3.

8. Ana Inés LANGER, 2010, p.61.

9. Which she defines as "the emphasis in public discourse not just on leaders, on their overall personalities, or on their leadership traits, but on their personal lives and qualities. In other words, this concept encompasses the emphasis on politicians not just as representatives of an ideology or a party, or as statesmen, but also as persons, as human beings." (Ana Inés LANGER 2011, p. 44).

10. The decision was made to include UKIP as the fourth "major party" (in addition to the Conservative Party, the Labour Party, and the Liberal-Democrats) in Great Britain even if it is only acknowledged as such in England and Wales in the latest Ofcom List of Major Parties. See Ofcom, Ofcom List of major parties, 16 March 2015, http://stakeholders.ofcom.org.uk/binaries/ broadcast/guidance/major-parties.pdf, accessed 31 May 2015.

11. David CAMERON, Interview with Tom BRADBY, Tonight: Special, Series 22, Episode 1, ITV, 7 April 2015; Nick CLEGG, Interview with Tom BRADBY, Tonight: Special, Series 22, Episode 2, ITV, 9 April 2015; Ed MILIBAND, Interview with Tom BRADBY, Tonight: Special, Series 22, Episode 3, ITV, 16 April 2015; Nigel FARAGE, Interview with Julie ETCHINGHAM, Tonight: Special, Series 22, Episode 4, ITV, 23 April 2015; Nigel FARAGE, Interview with James LANDALE, Leader profile, BBC, 6 March 2015; Ed MILIBAND, Interview with James LANDALE, Leader profile, BBC, 10 March 2015; Nick CLEGG, Interview with James LANDALE, Leader profile, BBC, 20 March 2015; David CAMERON, Interview with James LANDALE, Leader profile, BBC, 23 March 2015.

12. Both James Landale and Tom Bradby are political editors, Julie Etchingham's career only took a truly political turn in the election.

13. The Guardian's view was that "these [ITV] Tonight shows are more magaziney profilespersonality'n'politics, easy over." This also applies to the BBC Leader Profiles (Sam WOLLATSON, "Spotlight - Ed Miliband: Tonight review: 'Personality'n'Politics, Easy Over”, Guardian, 17 April 2015).

14. All the leaders under study were male.

15. Ana Inés LANGER, 2011 pp.79-81.

16. Ana Inés LANGER, 2011, p.80.

17. Ibid.

18. Max WEBER, Economy and Society, and Outline of Interpretative Sociology, Berkeley: University of California Press, 1968, p.241, quoted by Ana Inés LANGER, 2011, p.49.

19. Not to mention that it has been argued that "politics is increasingly about symbolism as opposed to policy implementation, image rather than content. As such, politicians can be viewed as 'actors' performing in a purposive way to achieve predetermined party political objectives." See Gareth SMITH, 
"Conceptualizing and Testing Brand Personality in British Politics", Journal of Political Marketing, vol. 8, n³, 2009, p.214.

20. James LANDALE, "Leader Profile: 24 hours with Nigel Farage”, bbc.co.uk, 6 March 2015, http:// www.bbc.co.uk/news/uk-politics-31771963, accessed 29 April 2015.

21. See note 46.

22. Ana Inés LANGER 2010, pp. 64-67 and 2011, chapter 6, pp. 139-159.

23. David SEAWRIGHT, “'Cameron 2010': An Exemplification of Personality-Based Campaigning”, Journal of Political Marketing, vol. 12, $\mathrm{n}^{\circ}$ 2-3, 2013, pp.166-181.

24. Ana Inés LANGER 2010, pp. 146-147.

25. Michael FOLEY, John Major, Tony Blair and a Conflict of Leadership: Collision Course, Manchester: Manchester University Press, 2002, p. 194, p.8.

26. Although he made the case that: "I think people have a right to know a bit more about you, your life and your family, what makes you tick, and what informs your thinking. And to me, nothing informs my thinking more than family because I think it's the most important thing there is in our society." ("Cameron defends filming of family", BBC News, bbc.co.uk, 14 March 2008, http:// news.bbc.co.uk/2/hi/uk_news/politics/7295735.stm, accessed 31 May 2015).

27. David CAMERON, 23 March 2015.

28. David CAMERON \& Ed MILIBAND, 26 March 2015.

29. It is mentioned in his official biography on the Labour Party website, and it was used as a setting on both his BBC ("where he said he learnt to stand up for himself") and ITV ("That's where it all started") portraits. (<http://www.labour.org.uk/people/detail/ed-miliband> accessed 31 May 2015; Ed MILIBAND, 10 March 2015; Ed MILIBAND, 16 April 2015).

30. D. CAMERON \& E. MILIBAND, Interview with Jeremy PAXMAN, op. cit.

31. The terms "bacon sandwich" are now the most googled alongside his name. (Jane MERRICK, "Ed Miliband's Trial by Media: Damned if he Does and Damned if he Doesn't", Independent, 15 March 2015).

32. Tim BALE, Five Year Mission-The Labour Party Under Ed Miliband, Oxford: Oxford University Press, 2015, p. 220.

33. Stephen SWINFORD, "Video: Ed Miliband Sounds like a Public Schoolboy", Daily Telegraph, 20 February 2015.

34. Ashley COWBURN, "Exclusive: Labour MP says the Public Thinks Ed Miliband is Aloof and more of a Toff than Cameron", New Statesman, 23 March 2015.

35. In the panel part of The Battle for Number Ten (D. CAMERON \& E. MILIBAND, 26 March 2015) and on his ITV piece (Ed MILIBAND, 16 April 2015).

36. <http://www.labour.org.uk/people/detail/ed-miliband>, accessed 29 April 2015.

37. D. CAMERON \& E. MILIBAND, 26 March 2015; Ed MILIBAND, 16 April 2015).

38. Raphael BERH, “The Making of Ed Miliband”, Guardian, 15 April 2015.

39. "Ed Miliband-a Portrait", Labour Party PEB, 28 April 2015, <http://labourlist.org/2015/04/edmiliband-a-portrait/> accessed 29 April 2015.

40. Nick CLEGG, Interview with Evan DAVIS, BBC Leader Interviews, BBC, 13 April 2015.

41. Ibid; Nick CLEGG, 9 April 2015; Nick CLEGG, 20 March 2015.

42. Nigel FARAGE, Interview with Evan DAVIS, BBC Leader Interviews, BBC, 22 April 2015.

43. Nigel FARAGE, Interview with Julie ETCHINGHAM, 23 April 2015.

44. Nigel FARAGE, Interview on Loose Women, ITV, 5 March 2015.

45. Ibid.

46. Two thirds of UKIP voters are male, making it "by far the most male-dominated party in Britain". (Jake WALLIS SIMONS, “Why are so Many Men Attracted to Ukip?", Daily Telegraph, 26 February 2015).

47. James LANDALE, 6 March 2015. If staying away from the pub may result in a more “ professional, less jokey" persona for Farage, it is worth noting that both Nick Clegg and Ed Miliband 
called upon the softening powers of the most traditionally British of décors in their BBC and ITV pieces respectively (Nick CLEGG, 20 March 2015; Ed MILIBAND, 16 April 2015).

48. Farage's father had a drinking problem and left when he was still a child.

49. Ana Inés LANGER, 2010, p. 66.

50. For analytical purposes, the focus in this part will be on the stage-management of the leaders as fathers, though their role as parents is obviously encompassed in their broader role as family men, which also includes their role as husbands and can hardly be separated from it since their wives are their children's mothers. Indeed, it is worth noting that all the leaders' families who received media coverage are "traditional" in the sense that all children were born of their marriage. The Milibands stand out slightly because their sons were born out of wedlock, but they did "regularize" their situation by getting married eventually. Nigel Farage, always the outsider, is the only one in his second marriage after a divorce, and whose children have different mothers.

51. Ed MILIBAND, 10 March 2015.

52. The use of the word "dad" by the three main party leaders, and even "daddy", in the case of Cameron and Miliband, that is to say of the name they are called by their children, to refer to themselves as fathers, is a simple, touching way of projecting themselves in that role by showing emotional connection.

53. Nick CLEGG, 20 March 2015.

54. David CAMERON, 7 April 2015.

55. He was quoted by Julie Etchingham as she interviewed him for ITV (Nigel FARAGE, 23 April 2015).

56. Yet pictures of the Prime Minister's children can easily be found on the Internet, and Samantha Cameron's Mail on Sunday interview included photographs of all of them (Geordie GRIEG, "Samantha Cameron: 'Dave runs the country; I do the school run'", Mail on Sunday, 4 April 2015).

57. Nigel FARAGE, 23 April 2015.

58. See "the kitchen election".

59. Nick CLEGG, Call Clegg: Nick's Weekly LBC Phone-In, LBC, 12 March 2015.

60. Nick CLEGG, 6 March 2015.

61. David CAMERON \& Ed. MILIBAND, 26 March 2015.

62. Nick CLEGG, Call Clegg: Nick's Weekly LBC Phone-In, LBC, 12 March 2015.

63. Ibid.

64. David CAMERON, Interview with Susanna REID, Good Morning Britain, ITV, 17 March 2015.

65. David CAMERON, 23 March 2015.

66. David CAMERON, 7 April 2015.

67. Nick Clegg and his wife are here referred to as "the Cleggs" for the sake of convenience, and by no means in accordance with the rightwing press's pratice to call Miriam Gonzáles Durántez "Miriam Clegg" in jingoistic ignorance of the Spanish tradition concerning married women's surnames.

68. Nick CLEGG, 12 March 2015.

69. Nigel FARAGE, 5 March 2015.

70. However, the extent of the damage remains to be seen: though he did take the risk of alienating the women presenters of the show and their primarily female audience, he also comforted his electorate in their traditional approach to gender roles.

71. The only hint given as to their childcare arrangements during the campaign was when his wife Miriam said that he took his children to school in her talk at the Grazia Feminism: Then, Now and Tomorrow conference in February. ("Londoner's Diary: Miriam González Durántez: MPs can learn it all at the school gates", Evening Standard, 27 February 2015). 
72. Pamela OWEN, "Nigel Farage: 'If I lose I may quit politics to become a house husband", Daily Mirror, 11 April 2015.

73. Ed MILIBAND, Interview with Ben SHEPARD, Good Morning Britain, ITV, 25 March 2015.

74. David CAMERON, 7 April 2015.

75. Which was reminiscent of Tony Blair's much commented upon 1997 kitchen PEB. See Ana Inés LANGER, 2010, p. 63.

76. Tim SHIPMAN, “Cameron's Just a 'Sad Dad' to his Daughter”, Sunday Times, 12 April 2015.

77. The Milibands gave a very simple visual hint in that area: indeed, their boys could be seen riding pink scooters on the $\mathrm{BBC}$ piece.

78. Michael HIGGINS \& Angela SMITH, “'My Husband, My Hero': Selling the Political Spouses in the 2010 Election", Journal of Political Marketing, vol. 12, n 2-3, 2013, p. 197.

79. Michael HIGGINS \& Angela SMITH, art. cit., p.199.

80. Ruth E. PAGE, "Cherie: Lawyer, wife, mum: Contradictory patterns of representation of media reports of Cherie Booth/Blair”, Discourse \& Society, vol. 14, n5, pp.559-579, quoted in Michael HIGGINS \& Angela SMITH, ibid.

81. Ed Miliband's wife practices law under her maiden name. Her first major interview on the BBC with James Landale was the first time she used her husband's surname in public.

82. Natasha WALTERS, Living Dolls: The return of sexism, London: Virago, 2010, p.224, quoted in Michael HIGGINS \& Angela SMITH, ibid.

83. She pointed the fact out herself, in her above-mentioned Grazia talk (see note 71), with a degree of humour and irony: "Apparently I was a terrible person because I was depriving my husband, who has a 'really, really important job', from being in yet another meeting because, poor thing, I was forcing him to take his children to school. Have you actually thought about how stupid it is to think we are 'forcing' men - men want to be with their children." ("Londoner's Diary: Miriam González Durántez: MPs can learn it all at the school gates", Evening Standard, 27 February 2015).

84. David CAMERON, 23 March 2015.

85. Ben GLAZE, "Nick Clegg's wife delivers slap down to David Cameron for living in a 'bubble"”, Daily Mirror, 9 April 2015.

86. Ed MILIBAND, Interview with James LANDALE, op. cit.

87. As a matter of fact, she ranked 15th most prominent individual in terms of press and television news coverage in the formal campaign, as monitored by the Loughborough University, three places behind Green Party leader Natalie Bennett, and two places ahead of Leanne Wood, leader of Plaid Cymru. This pointed out to the fact that the women party leaders failed to have much of an impact on the coverage. See Emily HARMER, "Men Writing About Men: Media And The UK General Election 2015", Loughborough University blog, 22 May 2015, http:// blog.lboro.ac.uk/general-election/men-writing-about-men-media-and-the-uk-generalelection-2015/, accessed 31 May 2015.

88. David CAMERON, 23 March 2015; David CAMERON, 7 April 2015.

89. Geordie GRIEG, "Samantha Cameron: 'Dave Runs the Country; I Do the School Run'“, Mail on Sunday, 4 April 2015.

90. Nick CLEGG, 9 April 2015. This was interpreted as an attack on David Cameron. See GLAZE, Ben, art. cit.

91. James LANDALE, "A chat with Justine Miliband", bbc.co.uk, 10 March 2015, <http:// www.bbc.com/news/uk-politics-31825792>, accessed 29 April 2015.

92. <http://www.labour.org.uk/people/detail/ed-miliband>, accessed 31 May 2015.

93. Surprisingly enough, Nick Clegg even exceeded expectations to a certain extent, by letting the BBC in his parents' home, although this may have been simply been in compensation for, or even to create a diversion from, not having them in his own.

94. Pamela OWEN, art. cit. 
95. Ben RILEY-SMITH, “Ed 'Two Kitchens' Miliband under Fire in Bizarre Row”, Daily Telegraph, 12 March 2015.

96. Both on her LBC interview (Miriam GONZÁLES DURÁNTEZ, Interview with Shelagh Fogarty, Live on LBC, LBC, 25 March 2015) and in her Musmnet Q\&A (Miriam GONZÁLES DURÁNTEZ, Webchat, Mumsnet.com, <http://www.mumsnet.com/Talk/mumsnet_live_events/2359918Webchat-with-Miriam-Gonz-lez-Dur-ntez-Tues-21st-April-11-30-am?pg=5>, accessed 31 May 2015).

97. The name of the blog, mumandsons, speaks for itself as to how the Clegg boys are raised in a spirit of gender equality (see note 77).

98. Sarah VINE, "Why their Kitchen tells you All you Need to Know about the Mirthless Milibands... and why there's Nothing to Suggest that Ed and Justine are not, in Fact, Aliens", Daily Mail, 12 March 2015.

99. Eleanor MILLS, “Why Voters don't Feel at Home with Ed”, Sunday Times, 15 March 2015.

100. See for instance Rachel HALLIWELL, "Politicians: Get out of the Kitchen (but not before Showing us your Smeg)", Daily Telegraph, 25 March 2015.

101. Miriam GONZÁLES DURÁNTEZ, 25 March 2015.

102. Tom KNOWLES, "No Kitchen Sink Dramas as Cleggs Let TV Crew into Home", Times, 9 April 2015.

103. H. WALLOP \& M. OLIVER. “The 45 Secrets of David Cameron's Middle Class Kitchen” Daily Telegraph, 20 March 2015, and Sarah RAINEY, "Inside the Camerons' OTHER Kitchen - with its £22 Ikea Ceiling Lights, £239 John Lewis Food Processor, a £87 Panasonic Bread Maker - and a Calm Down Dear Chopping Board", Daily Mail, 24 March 2015.

104. Tim STANLEY, "British politics has a surfeit of kitchens and a deficit of ideas", Daily Telegraph, 16 March 2015.

105. As Harold Wilson famously did by smoking a pipe in public instead of the cigars he enjoyed in private. Tim STANLEY, ibid.

106. Ibid.

107. Ana Inés LANGER, 2010, pp.71-72.

108. See Tim STANLEY, art. cit., but also for example Hillary ROSE, "Never Mind the Cabinet: this Election is Being Fought in the Kitchen”, Times, 19 March 2015, or Dan HODGES, "I couldn't Care less about Ed Miliband's Kitchen", Daily Telegraph, 13 March 2015.

109. Ana Inés LANGER, 2010, p.61.

\section{ABSTRACTS}

This article focuses on a specific aspect of the leaders of the four main British parties' imagebuilding strategies in the 2015 campaign-the stage-management of their private lives. Indeed, family life is used as a key instrument in the construction of a particular dimension of the leaders' public personality theorised by Ana Inés Langer as the "private persona." Based primarily on a televised corpus, it seeks to analyse the political messages that were conveyed through public fatherhood. In addition, attention is devoted to the involvement of the leaders' wives.

Cette étude propose d'examiner un aspect particulier de la construction de l'image des leaders des quatre principaux partis politiques britanniques dans le cadre de la campagne électorale de 2015: les mises en scènes de leur vie privée. L'instrumentalisation de la vie familiale joue en effet 
un rôle clé dans l'élaboration de la dimension de la personnalité des leaders théorisée par Ana Inés Langer sous le nom de "persona privée ». Il s'agira notamment d'étudier, à partir d'un corpus essentiellement télévisuel, les messages politiques qui peuvent être projetés à partir de leurs rôles en tant que pères de famille. L'implication de leurs épouses sera également l'objet d'une attention particulière.

INDEX

Mots-clés: persona privée, communication, David Cameron, Nick Clegg, Nigel Farage, Ed Miliband

Keywords: public relations, private persona, David Cameron, Nick Clegg, Nigel Farage, Ed Miliband

\section{AUTHOR}

\section{SABINE MICHELON}

Université Paris 3 Sorbonne-Nouvelle 